\title{
THE INFLUENCE OF CSR PRACTICES ON ECONOMIC SUSTAINABLE PERFORMANCE
}

\author{
Abdullah Abdulaziz-Alhumaidan ${ }^{1}$ \\ School of Management, Universiti Sains Malaysia. \\ (Email: abdullah_alhumaidan@outlook.com) \\ Noor Hazlina Ahmad ${ }^{2}$ \\ School of Management, Universiti Sains Malaysia \\ (Email: hazlina@usm.my)
}

Received date: $30-05-2019$

Revised date: 22-07-2019

Accepted date: 03-09-2019

Published date: 15-09-2019

To cite this document: Abdulaziz-Alhumaidan, A., \& Ahmad, N. H. (2019). The Influence of CSR Practices on Economic Sustainable Performance. International Journal of Entrepreneurship and Management Practices, 2 (7), 26-38.

DOI: $10.35631 /$ ijemp. 27004

Abstract: The study aimed to investigate the role of CSR practices on economic sustainable performance, and it applied stakeholder theory. Further, the framework has been developed based on previous research. A quantitative method has been chosen for the research, with random convenience technique. The sample of the study is small manufacturers in Tunisia, and 53 questionnaires have been analyzed. The findings have provided that socially responsible practices have not effected on enterprises' economic sustainable performance. However, the study has provided further explanations, discussion, and a direction for future research.

Keywords: Corporate Social Responsibility (CSR), Economic Sustainable Performance, Stakeholder Theory, Small Enterprise

\section{Introduction}

Keeping business competitiveness and sustainable is an example of challenges that managers have to take into account in very dynamic environment (Bos-Brouwers, 2010; Ciemleja \& Lace, 2011). Economic sustainable performance is a significant factor for firms in particular small enterprises to meet their main goal, which is profit, consequently, these enterprises could protect their market share in such complexity business arena (Golini, Longoni \& Cagliano, 2014; Vachon \& Mao, 2008; Adam, Mahadi \& Rahman, 2018). However, enterprises may need to change their strategies in order to deal with this challenge, and thinking differently than competitors do; for instance, considering society's desires and needs (Schaltegger \& Burritt, 2010; Fuller \& Tian, 2006) 
However, local community and other stakeholders have made more pressure against businesses for contributing on their concerns; in other words, they call these enterprises to be environmental and social responsible (Eweje, 2014; Jose \& Chacko, 2017; Azid \& Tahir, 2019). Therefore, engaging in social activities could be seen as a starting point to economic sustainable performance (Ciemleja \& Lace, 2011; Rexhepi, Kurtishi, \& Bexheti, 2013; Hooi et al., 2016). Thus, Corporate social Responsibility (CSR) is widely believed to have a central function on financial performance despite there is an argument of nature of their correlations (Stewart \& Gapp, 2014; Baumgartner, 2014). For example, operating socially responsible satisfies stakeholders and prevents negative reactions from them (Nulkar, 2014). Besides, smaller enterprises could rethink to practice socially responsible due to it can be seen as a win-win strategy. This commitment has several marketing advantages such as loyalty, reputation, and word of mouth. Moreover, owners may pay attentions on the most significant practices to lead to economic sustainable performance. Hence, responding to their demands is a new way of rebuilding the relationship between organizations and wider community regardless the degree of implement and commitment across them since it might be different (Porter \& Kramer, 2006; Davidson, 2009). Therefore, there is a need for linking those concepts in business strategy (Emeseh \& Songi, 2014; Kozubek, 2015).

Though literature has provided insights about these relationships, it has yet to present conclusive evidence since contradictory results have been generated. Further, majority of studies were carried out in developed economies, and we do not know much in developing economies, in particular in Arabic context such as Tunisia (Stewart \& Gapp, 2014). Besides, smaller enterprises have been relatively ignored in comparison with larger corporations (Windolph, Schaltegger, \& Herzig, 2014). However, owners have to address new challenges in order to keep their enterprises sustainable whether financially or non-financial gains.

The research seeks to make a contribution on stakeholder theory via empirical evidence, and how the theory could lead to better outcomes as it recommended. Additionally, studies have investigated in vary contexts such as cultures and countries, and few of them have examined economic sustainable performance in eastern context particularly in Arabic societies; therefore, studying these variables in different states may present new insights of enterprises' outcomes. For instance to answer, why some firms are sustainable whereas others are not?

Thus, the study aims to address research gaps with respect to the relationship between CSR practices and economic sustainable performance. Therefore, manufacturing sector in Tunisia is examined since its role on the country's economy and employment. However, 39 small manufacturers are investigated to address the research objectives.

\section{Literature Review}

Economic performance has been defined differently; some of those definitions were focused on financial sides, whereas others provided broader concepts. For example, Vachon and Mao (2008) have defined it as an organization's ability to produce continual profits and secure liquidity. Franzonis (2015) sees it economic benefits for an organization and all its stakeholders Further, Labuschagne, Brent \& Van Erck (2005) concentrated on others' views and defined it as corporations economic values that perceived by stakeholders. Thus, as illustrated different perspectives for economic sustainable performance, but the focal point is financially benefit. 
Previous research shows that companies could broader their visions and having other strategies for performance (Ismail et al., 2018). For instance, operating ethically; that might lead to cost reduction for daily operations, and energy consumption, wastes (Maletic et al., 2015), securing competitive advantage (Winter \& Knemeyer, 2013); in consequence, reduce the total production costs (Yusuf et al., 2013). Hoffman and Ventresca (1999) proposed that manufacturers incorporate environmental and social practices in their processes can take advantages like cost saving since there is reduction of resources in production processes and consumption (Chin, Yean \& Yahya 2018). Adams (2002) has argued these advantages may improve brand image as a result higher profitability.

However, these activities are seen from stakeholders' perspectives because of social responsibility have interpreted differently. CSR definitions are developed over the time once first written of it in 1950s (MacKinnon, Coxe, \& Baraldi, 2012). World Business Council for Sustainability development (WBCSD) definition is focused on firms' roles towards local community and employees to improve the quality of life (WBCSD, 1999). European Commission (EC, 2001) defines it as voluntary efforts to incorporate ecological and social concerns into their activities. McWilliams and Siegel (2001) see it as actions to expand social practices beyond an enterprise's interests.

Enterprises likely to benefit from those practices in several facets; for instance, recruitment skilled employees (Bernhut, 2002), enhance their images (Nejati et al, 2017), a better relationship with all stakeholders (Adams, 2002), clients also tend to support these enterprises (Schuler \& Cording, 2006). Furthermore, shareholders feel is not risky to invest with socially responsible corporations (Mahmood \& Humphrey, 2013). Fortunately, smaller firms are better compared with larger companies in regard to manage the relationships with stakeholders due to they have personal contacts with them (Ellerup Nielsen \& Thomsen, 2009). Vincenza Ciasullo \& Troisi (2013) outlined that in spite the main objective for enterprises is economic outcomes, complying with society standards and consuming environmentally could be as an investment, as a result will contribute to better performance, besides, it leads to improve the relationships with stakeholders.

In addition, large and multinational firms prioritize socially and ecologically responsible organization, in particular, to supply raw materials (Nair \& Sodhi, 2012). Local communities are also belivied to have an impact role since they are monitoring organizations' operations; moreover, they are expecting positive effects from these enterprises on their community (Artiach et al., 2010). Keeble (2003) suggests that the dialogue between key stakeholders and companies to have a clear understanding of each part expectations; however, some differences between external and internal views are expected towards social responsibility. Further, corporations should realize that satisfying stakeholders is a main objective in spite different thoughts towards some challenges across them (de Colle, Henriques, \& Sarasvathy, 2014; Rasche \& Esser, 2006).

On the other hand, smaller businesses do not always considering those issues due to different reasons. A significant reason that they believe their negative impacts on the environment and local community are at the lowest level (Pimenova, \& van der Vorst, 2004; Revell \& Blackburn, 2007). Furthermore, owners of these firms claim that investing on such issues is unjustifiable due to their clients will not pay extra for this investment (Williamson, LynchWood, \& Ramsay, 2006; Brammer, Hoejmose \& Marchant, 2012). In fact, they are responsible for up to $70 \%$ of world pollution (Gadenne et al., 2012). Kassel (2012) has 
mentioned that those enterprises characterized CSR as a choice unless it improves their economic values for sharholders. However, research highlights that because of businesses defined themselves a part of some society, they should comply with it standards and make such contribution to their development (Hiseh, 2009).

Abdul-Rashid et al., (2017) examined sustainable practices effects on sustainable outcome across manufacturing corporations. They resulted that the sector has satisfied social practices; consequently, economic sustainable performance is enhanced. Gadenne et al., (2012) investigated social responsible practices and sustainable performance, the study has developed some measures. The results indicate that there is a positive correlation between these variables. Further, du Plessis \& Grobler (2014) found social responsible activities influence sustainability positively. Moreover, (Weber, 2008; Maletic et al., 2015) revealed positive causality relationships between CSR and economic performance. Vincenza Ciasullo \& Troisi (2013) have carried out a case study for making an exploration of moral practices across tactical levels. The study found that the level plays a vital role, and there is a noteworthy improvement regarding the organization's outcome. A study of Schaltegger and Burritt (2010) has highlighted that adopting ethical policy could lead to minimizing risks, differentiation, and cost reduction. Du Plessis and Grobler (2014) also investigated social responsible activities impact on sustainability. A comparative case study method is used to address the research objectives. They study has found a relationship between CSR practices and social, environmental, economic sustainability, despite the research is a case study, researchers believe that these issues should be examined across developing economies.

In contrast, Lopez et al., (2007) found a negative impact of CSR activities on economic sustainable performance, furthermore, Chih et al., (2010) have concluded no significant as well. Hillman and Keim (2001) resulted that practicing socially responsible is negatively related to shareholder's values. Hence, some of previous studies have reveled a positive correlation, on the other hand, others found no association or even a negative relationship (King \& Lenox, 2000; de Colle et al., 2014). Further research has concluded that no evidence to believe that moral practices commitment by necessarily can lead to desirable outcomes, which could be seen as contradictory with stakeholder theory (King \& Lenox, 2000; du Plessis \& Grobler, 2014). Besides, Worthington et al., (2006) research did not conclude a major role of external groups in opposition to small firms to employ social and environmental responsibility norms. Lopez et al., (2007) claimed that there are negative impacts of Business Social Responsibility (BSR) activities on sustainable performance, mainly in short term. Chih et al., (2010) concluded that there are no relationships of these practices with economic performance. Further, others (Hillman \& Keim, 2001; Morioka \& Carvalho, 2016) found that practicing socially is negatively related to shareholder's values, and does not always generate desirable outcomes, however, these studies provided vary conclusions (Baumgartner, 2014).

Thus, the study assumes social responsible practices have positive effects on economic sustainable performance; accordingly, the following hypotheses have been suggested:

H1: There is a positive effect of employees' social responsible practices on economic sustainable performance.

$\mathrm{H}$ 2: There is a positive effect of customers' social responsible practices on economic sustainable performance. 
H3: There is a positive effect of suppliers' social responsible practices on economic sustainable performance.

H4: There is a positive effect of environmental social responsible practices on economic sustainable performance.

H5: There is a positive effect of community social responsible practices on economic sustainable performance.

Studying BSR and sustainable performance explains the nature of the correlation between an enterprise and its stakeholder (Jain \& Winner, 2016). Stakeholder theory illustrates that firms can take advantages from sustainable performance when operating ethically to avoid such negative reactions such as lawsuits and protests (Ngai, et al., 2014). Sarkis (2001) highlighted these manufacturers' environmentally practices like reducing wastes and pollution have positive significances on ecology sustainable performance. For instance, sustainable performance and CSR lead to clients' satisfaction and loyalty, brand equity, which in turns enhances the organization's market value (Lai, Chiu, Yang, \& Pai, 2010; Luo \& Bhattacharya, 2009). Smaller enterprises in particular could benefit from BSR due to the stereotype of those kinds of practices are for large and Multi National Enterprises (MNEs); thus, taking initiatives might improve these enterprises' image, in consequence performance (Shahedul Quader, Kamal, \& Hassan, 2016). However, many studies applied the theory with BSR and sustainability and they suggested that it can provide further insights for those factors (Jamali, Safieddine \& Rabbath, 2008).

Additionally, Collins et al., (2007) proposed that this theory is a useful approach for understanding economic sustainable performance. A view is supported by the theory that sustainable performance could generate positive financial benefits through managing the relationships with wider stakeholders (Artiach et al., 2010). Ngai et al., (2014) suggested that social and ecological activities will lead to sustainability, and it benefits both external and internal stakeholders due to it minimize risks. The threat can be seen in vary facets like protests and boycotts and so on; hence, addressing the needs of different groups might lead to better outcomes (Gelbmann, 2010; Ngai et al., 2014).

\section{Research Design}

The research adopted a quantitative method strategy, and it explains and predicts the relationship between the study variables (i.e. CSR practices and economic sustainable performance). A questionnaire has been used and distributed to collect required data. It has been handled to small enterprises' owners/managers across manufacturing sector in Tunisia; however, organization's level is chosen to be the unit of analysis.

\section{Sample}

The targeted population for the research is small enterprises' owners/managers across manufacturing sector in Tunisia. The sector has been chosen because of significant criticisms regarding its negative role in both society and natural environment. On the other hand, the sector is crucial since its contributions on Tunisian economy concerning GDP and employment (INS, 2017; Alrai, 2016; Rekik, 2017). Further, more than 30\% of Tunisian's manufacturers exports to Europe and other countries (Mattoussi \& Ayadi, 2017; INS, 2018). Thus, 39 small manufacturers have been examined in this study. 
Population size is often large to be covered; therefore, there is a need to choose appropriate representatives from them, which is called the sample (Sekaran, 2003). However, choosing an appropriate sample is a challenging issue due to ability to generalize the findings of studies. Thus, small firms in Tunisia have been chosen, and they identified as a full time size of employees with 10-49 workers in manufacturing sector (INS, 2017).

Further, each element of the population has an equal opportunity to be unit of analysis; probability- random sampling method has been chosen to achieve the research objectives.

\section{Measurements}

The questionnaire used five-point Likert scale to collect the data. The study has adopted (Spiller, 2000; Turker, 2009) measurements for CSR practices, whereas economic sustainable performance measurement for (Zhou et al., 2013) is adopted. However, these measures are validated previously and have been widely used (e.g. Nejati, Amran \& Hazlina Ahmad, 2014; Abdullah et al., 2016).

Table 1: Profile of the Sample

\begin{tabular}{llc}
\hline Constructs & Types & Percentage (\%) \\
\hline \multirow{2}{*}{ Gender } & Male & $68 \%$ \\
& Female & $32 \%$ \\
\multirow{2}{*}{ Position } & Owner & $33 \%$ \\
& Manager & $67 \%$ \\
\multirow{2}{*}{ Establishment Years } & Five Years and Less & $21 \%$ \\
& More than Five Years & $79 \%$ \\
\hline
\end{tabular}

\section{Results}

The research has used (AMOS 22) to analyze the data. The measurement model has been analyzed, and it reliability and validity were tested. Composite Reliability (CR) value is extracted as shown in table 2, these values should not be less than .70, further, Average Variance Extracted (AVE) has to be more than .50 (Bagozzi \& Yi, 1988). However, the study satisfied these conditions as can be seen in table 2 .

Table 2: The Measurement Analysis

\begin{tabular}{lcc}
\hline \multicolumn{1}{c}{ Constructs } & Composite Reliability \\
AVE & .85 & .66 \\
\hline Environmental Social Responsible Practices & .77 & .53 \\
Community Social Responsible Practices & .80 & .59 \\
Employees' Social Responsible Practices & .80 & .52 \\
Customers' Social Responsible Practices & .73 & .59 \\
Suppliers' Social Responsible Practices & .85 & .61 \\
Economic Sustainable Performance & & \\
\hline
\end{tabular}

Since the results of measurement model have met the standards, structural model has been tested. However, the study hypotheses have not been supported. In other words, CSR practices do not necessarily lead to economic sustainable performance as table 3 has depicted. 
Table 3: Results of Analysis

\begin{tabular}{cccc}
\hline Relationship & Estimate & P-value & Decision \\
\hline Environmental Practices \& Economic Performance & -.175 & .179 & Not Supported \\
Community Practices \& Economic Performance & .221 & .068 & Not Supported \\
Employees' Practices \& Economic Performance & -.102 & .465 & Not Supported \\
Customers' Practices \& Economic Performance & .262 & .064 & Not Supported \\
Suppliers' Practices \& Economic Performance & .022 & .874 & Not Supported \\
\hline
\end{tabular}

The role of environmental social responsible practices does not have significance on economic sustainable performance since P-value is .179 and standardized estimation has a negative value, which is -.175 ; therefore, $\mathrm{H} 1$ is rejected. Besides, community social responsible practices did not affect enterprises' economic sustainable performance due to the p- value is.068, and standardized estimation was.221, which leads to reject H2. Firms' social responsible practices towards employees have not found to be significant on economic sustainable performance due to p-value was .465 and estimates by -.102, so H3 is not supported. Customers 'social practices also do not have an influence on organizations' economic performance and p-value is .064 with standardized .262 that leads to reject $\mathrm{H} 4$ as well. Moreover, suppliers' social practices have not affected economic sustainable performance since p-value .874 and estimation is -.022; hence H5 has not been supported. Thus, the results show that economic sustainable performance is not determined by socially responsible practices within the context of this study.

\section{Discussion}

The research findings found that CSR practices have not effects on economic sustainable performance. These results depict that manufacturing small enterprises in Tunisia have practiced socially responsible, but these activities did not improve their economic performance, and many studies have arrived to similar results (e.g. Chih et al., 2010; Lopez et al., 2007; Hillman and Keim, 2001). However, we cannot generalize them to other contexts since Tunisia has its own circumstances in particular these years. For example, it faces high inflation, so prices have gone up; therefore, enterprises' managers do not believe that economic performance is enhanced, rather it becomes worse day by day. Thus, with these conditions owners hesitate to put more investments, and foreigners' investors took a back step, which in turns affect micro and macroeconomic. All in all, the external environment has influenced small manufacturers' economic sustainable performance despite they practice socially responsible.

\section{Implications}

The study provides further debate of the role of CSR on an organization's outcomes. The concept of social responsible practices has been debatable for decades, and still ongoing. However, these results can be seen as an index of the country's economy is vital to determine CSR outcomes. Therefore, research has concluded that stakeholder theory cannot be taken as promise for better achievement without understanding around context. It also adds to knowledge that paradoxical findings should be taken within the context of the study such as the country, sector etc. In other words, the state conditions have a vital role in determining how stakeholders' theory will be affected once it applied. Further, research contributes to knowledge through shed light on how the theory could affect economic sustainable performance although it did not achieve desirable expectations. 
In regard to managerial implications, enterprises' owners should not ignore internal and external business's domain once their firms practice socially responsible regardless the achievements. Though economic performance has not been improved, practicing environmentally and socially is the right thing to do for stakeholders. Additionally, it avoids fees and fines, particularly, across manufacturing sector. Moreover, the country context is a quarter stone in these cases, and owners should rethink whether the current practices fit the community's culture and needs. In other words, each society has its own necessitates that differ from others even in the same nation. In addition, policy makers can have a better contact with these firms in order to scrutinize and revise their ecology and socially practices to suggest and promote similar, or different activities. In particular, the government usually has better knowledge about each area's needs. Thus, it can co-operate with this sector for better achievements.

\section{Limitation and Future Research}

The study is not out of limitations; firstly, it investigated a single dependent variable, which is economic sustainable performance, future research may add other dependent factors such as environmental and social sustainable performance. Secondly, they could examine the role of moderators like innovation, it might strength, or weakness such relationship. Thirdly, the research has studied manufacturing sector, so other sectors have own contexts, which could enhance our understanding of them. Fourthly, the study is cross-sectional, and it concluded no significant; therefore, longitudinal investigation may provide other results since the study attributed the findings to economic circumstances. Lastly, it has examined owners/ managers views, and some of the results could impacted by their bias; hence, future research can investigate other stakeholders, for instance, employees, customers and suppliers. Though the research has several limitations, it provided some insights about small manufacturers regarding CSR and economic sustainable performance.

\section{Conclusion}

The research found that social responsible practices are not guarantee for economic sustainable performance in Tunisia across small manufacturers' enterprises. Moreover, it could conclude that CSR practices outcomes are influenced by the country's circumstances. For instance, some of other states in Arabic region may have gain better economic sustainable performance since they did not face the same conditions. Thus, each country and region has its own challenges.

Based on these results Tunisian' government has a role to play in this difficult period. They should revise its economic policy since taxes become higher, which in turn affect the outcomes of these firms as respondents claimed. Further, they need to discuss about these issues with enterprises' owners to arrive into a win-win strategy.

The proposed variables have been developed based on stakeholder theory, accordingly, the hypotheses have been developed as it suggested. Though the findings were inconsistence with the theory, several studies have concluded to similar results. Therefore, the conclusions can be seen within the context of the study sample. 


\section{References}

Abdul-Rashid, S. H., Sakundarini, N., Raja Ghazilla, R. A., \& Thurasamy, R. (2017). The impact of sustainable manufacturing practices on sustainability performance. International Journal of Operations \& Production Management, 37(2), 182-204.

Adam, S., Mahadi, B., \& Rahman, A. P. A. (2018). The effect of enterpreneurial orientation towards organizational performance of E-Business in Malaysia. International Journal of Entrepreneurship and Management Practices, 1 (2), 12-21.

Adams, A. (2002) "Internal organizational factors influencing corporate social and ethical reporting: beyond current theorizing". Accounting, Auditing \& Accountability Journal, Vol. 15 (2), 223-50.

Artiach, T., Lee, D., Nelson, D., \& Walker, J. (2010). The determinants of corporate sustainability performance. Accounting and Finance, 50(1), 31-51.

Azid, N.N.A., \& Tahir, P.R. (2019). Corporate social responsibility environment in Malaysia: Lessons learned from the effectiveness of the CSR programme By Axiata group. International Journal of Entrepreneurship and Management Practices, 2(5), 72-82.

Bagozzi, R. \& Yi, Y. (1988). On the Evaluation of Structural Equation Model. Journal of Academy of Marketing Science, 16(1), 74-94.

Baumgartner, R. (2014). Managing corporate sustainability and CSR: A conceptual framework combining values, strategies and instruments contributing to sustainable development. Corporate Social Responsibility and Environmental Management, 21, 258-271.

Bernhut, S. (2002). Corporate social responsibility. IVEY Business Journal, 66(4), 18-29.

Bos-Brouwers, H. (2010). Corporate sustainability and innovation in SMEs: Evidence of themes and activities in practices. Business Strategy and Environment, 19(7), 417-453

Brammer, S., Hoejmose, S., \& Marchant, K. (2012). Environmental management in SMEs in the UK: practices, pressures and perceived benefits. Business Strategy and the Environment, 21(7), 423-434.

Chih, L., Chih, H., \& Chen, T. (2010). On the determinants of corporate social responsibility: international evidence on the financial industry. Journal of Business Ethics, 79, 179198.

Chin, T., Yean, T., \& Yahya, K. (2018). Elucidating the bonds between organizational ethical climate and corporate environmental citizenship. Jurnal Pengurusan (UKM Journal of Management), 54.

Ciemleja, G., \& Lace, N. (2011). The model of sustainable performing of SMEs in context of company's life cycle. www.alephfiles.rtu.lv

Davidson, K. (2009). Ethical concerns at the bottom of the pyramid: where CSR meets BOP. Journal of International Business Ethics, 2 (1), 22-32.

de Colle, S., Henriques, A., \& Sarasvathy, S. (2014). The Paradox of Corporate Social Responsibility Standards. Journal of Business Ethics, 125(2), 177-191.

du Plessis, N., \& Grobler, A. F. (2014). Achieving sustainability through strategically driven CSR in the South African retail sector. Public Relations Review, 40(2, SI), 267-277.

Ellerup Nielsen, A., \& Thomsen, C. (2009). CSR communication in small and medium-sized enterprises. Corporate Communications: An International Journal, 14(2), 176-189.

Emeseh, E. \& Songi, O. (2014). CSR, human rights abuse and sustainability report accountability. International Journal of Law and Management, 56(2), 136-151.

European Commission (2001). Promoting a European framework for corporate social responsibility. Green Paper, European Commission, Brussels. 
Eweje, G. (2014). Introduction: trends in corporate social responsibility and sustainability in emerging economies. Governance and Sustainability, 8, 3-17.

Franzoni, S. (2015). Measuring the sustainability performance of the tourism sector. TMP, 16, $22-27$.

Fuller, T. and Tian, Y. (2006). Social and symbolic capital and responsible entrepreneurship: an empirical investigation of SME narratives. Journal of Business Ethics, 67 (3), 287304.

Gadenne, D., Mia, L., Sands, J., Winata, L., \& Hooi, G. (2012). The influence of sustainability performance management practices on organisational sustainability performance. Journal of Accounting \& Organizational Change, 8(2), 210-235.

Gelbmann, U. (2010). Establishing strategic CSR in SMEs: An Austrian CSR quality seal to substantiate the strategic CSR performance. Sustainable Development, 18(2), 90-98.

Golini, R., Longoni, A., \& Cagliano, R. (2014). Developing sustainability in global manufacturing networks: The role of site competence on sustainability performance. International Journal of Production Economics, 147(PART B), 448-459.

Hillman, A.J., Keim, G.D., (2001). Shareholder value, stakeholder management, and social issues: what's the bottom line? Strategic Management Journal, 22 (2), 125-139.

Hiseh, N. (2009). Corporate social responsibility and the priority of shareholders. Journal of Business Ethics, 88, 553-560.

Hoffman, A.J., \& Ventresca, M. (1999). The institutional framing of policy debates: economics versus the environment. American Behavioral Scientist, 42 (8), 1368-1392.

Hooi, H. C., Ahmad, N. H., Amran, A., \& Rahman, S. A. (2016). The functional role of entrepreneurial orientation and entrepreneurial bricolage in ensuring sustainable entrepreneurship. Management Research Review, 39(12), 1616-1638.

Ismail, M., Abdul Hamid, R., Che Senik, Z., Othman, A., \& Juhdi, N. (2018). SMEs export performance: The effect of learning orientation and innovativeness. Jurnal Pengurusan (UKM Journal of Management), 54.

Jain, R., \& Winner, L. H. (2016). CSR and sustainability reporting practices of top companies in India. Corporate Communications: An International Journal, 21(1), 3655.

Jamali, D., Safieddine, A., \& Rabbath, M. (2008). Corporate governance and corporate social responsibility: Synergies and interrelationship. Corporate Governance: An International Review, 16(5), 443-459.

Kassel, K. (2012). The circle of inclusion: Sustainability, CSR and the values that drive them. Journal of Human Values, 18(2), 133-146.

Keeble, J. J. (2003). Using Indicators to Measure Sustainability Performance at a Corporate and Project Level. Journal of Business Ethics, 44(2), 149-158.

King, A., \& Lenox, M. (2000). Industry self-regulation without sanctions: the chemical industry's responsible care program. Academy of Management Journal, 43, 698-716.

Khaleel, M., Chelliah, S., Rauf, S., Jamli, M. (2017). Impact of perceived corporate social responsibility on attitudes and behaviors of pharmacists working in MNCs. Humanomics, 33(4), 453-469.

Kozubek, R. (2015) 'The link between innovation and CSR. Short look on a-bi-directional system of innovation- driven CSR and CSR-driven innovation', www.woiz.polsl.pl

Kuckertz, A., Wagner, M. (2010). The influence of sustainability orientation on entrepreneurial intentions-investing the role of business experience. Journal of Business Venturing, 25(5), 524-539. 
Labuschagne, C., Brent, A. C., \& Van Erck, R. P. G. (2005). Assessing the sustainability performances of industries. Journal of Cleaner Production, 13(4), 373-385.

Lai, C., Chiu, C., Yang, C., \& Pai, D. (2010) The effects of corporate social responsibility on brand performance: the mediating effect of indutrial brand equity and corporate reputation. Journal of Business Ethics, 95, 457-469.

Lopez, M.V., Garcia, A., \& Rodriguez, L., (2007) "Sustainable development and corporate performance: a study based on Dow Jones sustainability index". Journal of Business Ethics, Vol.75, 285-300.

Luo, X., \& Bhattacharya, C.B. (2009). The debate over doing good: corporate social performance, strategic marketing levers and firm idiosyncratic risk. Journal of Marketing, Vol. 73, (6) 198-213.

MacKinnon, D. P., Coxe, S., \& Baraldi, A. N. (2012). Guidelines for the Investigation of Mediating Variables in Business Research. Journal of Business and Psychology, 27(1), 1-14.

Mahmood, M., \& Humphrey, J. (2013). Stakeholder Expectation of Corporate Social Responsibility Practices: A Study on Local and Multinational Corporations in Kazakhstan. Corporate Social Responsibility and Environmental Management, 20(3), 168-181.

Maletic, M., Maletic, D., Dahlgaard, J., Dahlgaard-Park, S. M., \& Gomišcek, B. (2015). Do corporate sustainability practices enhance organizational economic performance? International Journal of Quality and Service Sciences, 7(2/3), 184-200.

Morioka, S. N., \& Carvalho, M. M. (2016). Measuring sustainability in practice: exploring the inclusion of sustainability into corporate performance systems in Brazilian case studies. Journal of Cleaner Production, 136, 123-133.

Nair, N., \& Sodhi, J. (2012). CSR practices by SMEs in India: Lessons from five case studies. The Indian Journal of Industrial Relations, 47(4), 583-597.

Nejati, M., Amran, A., \& Hazlina Ahmad, N. (2014). Examining stakeholders' influence on environmental responsibility of micro, small and medium-sized enterprises and its outcomes. Management Decision, 52(10), 2021-2043.

Nejati, M., Quazi, A., Amran, A., \& Ahmad, N. H. (2017). Social Responsibility and Performance: Does Strategic Orientation Matter for Small Businesses? Journal of Small Business Management, 55(0), 43-59.

Ngai, E. W. T., Chau, D. C. K., Lo, C. W. H., \& Lei, C. F. (2014). Design and development of a corporate sustainability index platform for corporate sustainability performance analysis. Journal of Engineering and Technology Management - JET-M, 34, 63-77.

Nulkar, G. (2014). Does environmental sustainability matter to small and medium enterprises? Empirical evidence from India. International Journal of Environmental Studies, 71(4) 481-489.

Pimenova, P. \& van der Vorst, R. (2004). The role of support programmes and policies in improving SMEs environmental performance in developed and transition economies. Journal of Cleaner Production, 12(6), 549-559.

Porter, M., \& Kramer, M. (2006). Strategy and society: the link between competitive advantage and corporate social responsibility. Harvard Business Review, December 78-92.

Rasche, A., \& Esser, D. (2006). From stakeholder management to stakeholder accountabilityapplying Habermasian discourse ethics to accountability research. Journal of Business Ethics, 65(3), 251-267. 
Rekik, L., \& Bergeron, F. (2017). Green practice motivators and performance in SMEs: a qualitative comparative analysis. Journal of Small Business Strategy, 27(1), 1-17.

Revell, A., \& Blackburn, R. (2007). The business case for sustainability? An examination of small firms in the UK's construction and restaurants sectors. Business Strategy and the Environment. 16, 404-420.

Rexhepi, G., Kurtishi, S., Bexheti, G. (2013). Corporate social responsibility and innovationthe drivers of business growth? Social and Behavioral Sciences, 75, 532-541.

Sarkis, J. (2001). Manufacturing's role in corporate environmental sustainability. International Journal of Operations \& Production Management, 21 (5), 666-686.

Schaltegger, S., and Burritt, R. (2010) "Sustainability accounting for companies: catchphrase or decision support for business leaders?” Journal of World Business, Vol.45, (4), 375384.

Schuler, D. A., \& Cording, M. (2006). A corporate social performance-corporate financial performance behavioral model for consumers. Academy of Management Review, $31(3), 540-558$.

Sekaran, U. (2003). Research methods for business, Fourth Edition, John Wiley, NY.

Shahedul Quader, M., Kamal, M. M., \& Hassan, A. B. M. E. (2016). Sustainability of positive relationship between environmental performance and profitability of SMEs. Journal of Enterprising Communities: People and Places in the Global Economy, 10(2), 138163.

Spiller, R. (2000). Ethical business and investment: A model for business and society. Journal of Business Ethics, 27(1), 149-160.

Stewart, H., \& Gapp, R. (2014). Achieving effective sustainable management: A smallmedium enterprise case study. Corporate Social Responsibility and Environmental Management, 21(1), 52-64.

Story, J., \& Neves, P. (2015). When corporate social responsibility (CSR) increases performance: exploring the role of intrinsic and extrinsic CSR attribution. Business Ethics: A European Review, 24(2), 111-124.

Turker, D. (2009). Measuring corporate social responsibility: a scale development study. Journal of Business Ethics, 85(4), 411-427.

Vachon, S., \& Mao, Z., (2008). Linking supply chain strength to sustainable development: a country-level analysis. Journal of Cleaner Production. Vol. 16, 1552-1560.

Vincenza Ciasullo, M., \& Troisi, O. (2013). Sustainable value creation in SMEs: a case study. The TQM Journal, 25(1), 44-61.

Weber, M. (2008). The business case for corporate social responsibility: A company-level measurement approach for CSR. European Management Journal, 26(4), 247-261.

Williamson, D., Lynch-Wood, G., \& Ramsay, J. (2006). Drivers of environmental behaviour in manufacturing SMEs and the implications for CSR. Journal of Business Ethics, 67(3), 317-330.

Windolph, S., Schaltegger, S., \& Herzig, C. (2014). Implementing corporate sustainability what drives the application of sustainability management tools in Germany? Sustainability Accounting Management and Policy Journal, 5 (4), 378-404.

Winter, M., \& Knemeyer A. (2013). Exploring the integration of sustainability and supply chain management: current state and opportunities for future inquiry. International Journal of Physical Distribution \& Logistics Management, 43 (1), 18-38.

World Business Council for Sustainable Development (WBCSD) (1999). Corporate social responsibility. Meeting changing Expectations, Conches-Geneva. 
Worthington, I., Ram, M., \& Jones, T. (2006). Exploring corporate social responsibility in the UK Asian small business community. Journal of Business Ethics, 67(2), 201-217.

Yusuf, Y., Gunasekaran, A., Musa, A., El-Bberishy, N.M., Abubakar, T., \& Ambursa, H. (2013). The UK oil and gas supply chains: an empirical analysis of adoption sustainable measures and performance outcomes. International Journal of Production Economics, 146 (2), 501-514. 